УДК: $16: 37.01$

\title{
Олександр ТяГЛО
}

\section{ДОСВІД ЗАСВОЄННЯ КРИТИЧНОГО МИСЛЕННЯ В УКРАЇНСЬКІЙ ВИЩІЙ ШКОЛІ}

В статті аргументовано, що у ХХІ столітті запити на критичне мислення (КМ) визначаються потребами як політичної надбудови, так і продуктивних сил конкурентноздатного суспільства. Феномен КМ потрібно вивчати і осмислювати як

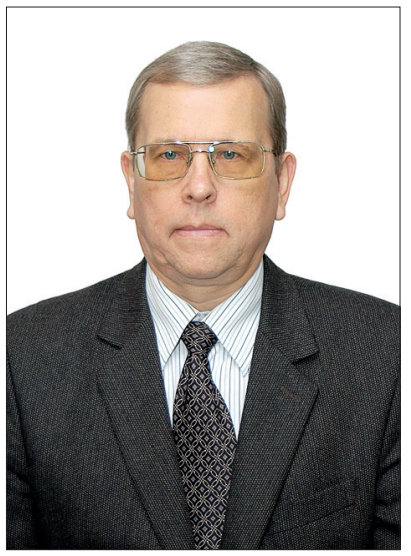
один з суттєвих елементів складніших утворень мислення вищого порядку, сукупності серцевинних для праці вмінь тощо. Вміння КМ слід розвивати у зв'язку з відповідними когнітивними і афективними диспозиціями. Тож наголошено, що правильнішим є не обмежуватися навчанням KM, а виховувати критично мислячу особу, в якої вміння КМ спиратиметься на підвалини відповідних диспозицій. Процес виховання критично мислячої особи, а вірніше - особи, яка матиме КМ, наприклад, у складі сукупності серцевинних для ї̈ праці вмінь, має охоплювати, щонайменше, дошкільну, шкільну й університетську освіту. Обгрунтовано, що за умов української вищої школи в процесі виховання КМ доцільно використовувати зв'язку двох курсів: логіки з елементами критичного мислення - у межах бакалаврату - $i$ критичного мислення на основі логіки - у межках магістратури.

Ключові слова: критичне мислення, критично мисляча особа, мислення вищого порядку, серцевинні для праці вміння, вища школа України.

Хоча критика стара як світ, критичне мислення (КМ) у тому розумінні, в якому воно розглядатиметься у моїй статті, з'явилось лише у другій половині XX століття. Це динамічне явище на перетині низки полів соціального простору, зокрема освіти, науки, політики і економіки, було викликане до життя становленням інформаційного суспільства. Поява протягом останніх десятиліть у середовищі глобального інформаційного суспільства зародків суспільств знань, розгортання Четвертої індустріальної революції й інші новітні процеси лише підвищують актуальність КМ.

В Україні сьогодні «Критичне мислення» - розкручений бренд. Однак досить часто ним прикривають вульгаризовані чи суто кон'юнктурні ідеї або навіть повчання, котрі спотворюють сутність КМ, вносять плутанину у цілі й засоби його виховання (Терно, 2012; Тягло, 2017). 3 огляду на сказане у пропонованій статті представлене одне з розумінь КМ, наявного стану і перспектив його виховання у вітчизняній системі освіти, головно - вищої. 


\section{Мій бекграунд у КМ}

У спільноті вчених людей існує звичка звертати увагу на обізнаність промовця чи автора публікації саме в обговорюваній темі, зважати на його, як кажуть, бекграунд. Принаймні спершу ця обставина визначає читати або не читати опубліковане. Тож аби заохотити потенційного читача витратити часточку свого часу на ознайомлення з пропонованою статтею, розпочну з короткого опису власного бекграунду у КМ. Окрім того, його врахування допоможе читачеві адекватно сприйняти сказане далі по суті.

Першим знайомством з проблематикою КМ я зобов'язаний українсько-канадському професору Тарасу Даниловичу Закидальському (1941-2007). Він представив цю проблематику учасникам семінару «Трансформація гуманітарної освіти в Україні», проведеному у жовтні 1995 року Харківським благодійним фондом «Центр освітніх ініціатив» за підтримки міжнародного фонду «Відродження». Увійшовши у резонанс з моєю викладацькою практикою, інформація Т. Д. Закидальського стимулювала модифікацію навчального курсу логіки i, зрештою, створення брошури «Логіка критичного мислення (у конспективному викладі)» (Тягло, 1996). Це була обмежена початкова робота, але в ній, серед іншого, вже відзначена перспектива взаємного збагачення традиційного для вищої школи України курсу логіки і заокеанської новації, визначений пріоритет логічного аспекту в подальших студіях КМ. Протягом двох наступних років був розроблений і виданий навчальний посібник «Логіка з елементами курсу критичного мислення» (Тягло, 1998).

У 1998 році - через Раду міжнародних досліджень і обмінів (IREX) за підтримки Інформаційної агенції США - доля подарувала мені можливість протягом осіннього семестру пройти стажування в університеті міста Боулін Грін (Огайо, США). Тут я, серед іншого, відвідував класи з КМ двох авторитетних у Сполучених Штатах професорів, авторів навчального посібника, що витримав на той час вже п'ять видань - Нейла Брауна і Стюарта Кілі (Browne and Keeley, 1998)'․ Головним моїм здобутком стало засвоєння алгоритму КМ через висування сукупності «nравильних запитань», котрі відповідають послідовним стадіям аналізу, розуміння і критичної оцінки проблемного повідомлення. Тож один зі способів навчання мислити критично полягає у поданні цих «правиль-

${ }^{1}$ Професори Браун і Кілі працювали з першокурсниками, які не вивчали науку логіки. Тому засвоєння КМ спиралося, перш за все, на притаманну нормальній людині природну логіку, або здоровий глузд, а також на базис відповідних диспозицій, знань і вмінь, набутих раніше. 
них запитань» і у формуванні готовності та вмінь їх доцільно ставити, влучно на них відповідати ${ }^{1}$.

Адаптація набутих «з перших рук» знань і досвіду до умов вітчизняної вищої освіти дозволила краще реалізувати ідею «схрещування» звичного для наших вишів викладання логіки і американського КМ. У результаті було створено два основних продукти: навчальні курси логіки з елементами критичного мислення та критичного мислення на основі науки логіки.

Влітку 2001 року я взяв участь у Міжнародній науково-практичній конференції «Демократія і освіта», організованій Кіровоградським державним педагогічним університетом ім. Володимира Винниченка та Центром глобальної освіти університету Монтклер (Нью Джерсі, США). На підставі виступу і особистого спілкування керівник Центру глобальної освіти Марина Каннінгем запросила мене відвідати університет Монтклер, один з провідних центрів США з розробки і впровадження КМ у дошкільній, шкільній та університетській освіті. Візит відбувся протягом осіннього семестру 2005 року: я мав нагоду різнобічно поспілкуватися з професором Метью Ліпманом (1922-2010) і його співробітниками - Марком Вайстейном, Моном Грегорі та ін. В результаті у вітчизняних виданнях з'явилась низка перекладів праць американських фахівців (Ліпман, 2005), (Вайнстейн, 2005), (Грегорі, 2006), а також аналіз їх науково-педагогічного доробку, актуального для наших освітян (Тягло, 2005). Зрештою вплив відвідування університету Монтклер призвів до доповнення мого курсу КМ частинами з творчого мисленням і основ композиції (Тягло, 2008).

Я прагну поповняти і розвивати свою обізнаність у КМ та дотичній проблематиці дотепер. Загалом мою позицію можна ідентифікувати як таку, що спирається на розуміння КМ, вироблене у межах північноамериканської традиції регулярної освіти². Доволі широке річище

\footnotetext{
1 Зібрана під час стажування в університеті Боулін Гріна інформація і перші результати її опрацювання були представлені, зокрема, у книзі «Критичне мислення: проблема світової освіти XXI століття» (Тягло і Воропай, 1999).

${ }^{2}$ Ця традиція має як збіги, так і суттєві розбіжності 3 «революційною критичною педагогікою» Пауло Фрейре, Генрі Жиру, Пітера Макларена та ін., котра виробила власне розуміння КМ. Оскільки розгляд критичної педагогіки виходить за межі даної статті, то обмежусь лише одним висновком, запозиченим з досить ретельного дослідження Ніколаса Бурбуліса і Руперта Берка. 3 точки зору прихильників критичного мислення, вказують американські фахівці, критична педагогіка переходить межу між навчанням критичності (criticality) й індоктринуванням (indoctrinating). Навчання мислити критично повинно надавати можллвість доходити своїх власних висновків, натомість критична педагогіка небезпечно наближається до навіювання того, якими висновки мають бути... критичне мислення, по суті, вчить мислити критично, але не політично, тоді як критична педагогіка вважає таку дистинкцію помилковою... (Burbules and Berk, 1999 : p. 54-55). Див. також (Макларен, 2010; Гайденко, 2006).
} 
цієї традиції окреслене, зокрема, у виконаному майже тридцять років тому дослідженні КМ з залученням провідних фахівців США та Канади (Facione, 1990). Тож розгляну далі деякі основні його результати.

\section{що $є \mathrm{KM}$ ?}

До середини 80-х років минулого століття у Північній Америці феномен КМ досяг такого рівня суспільної затребуваності і поширення, який не тільки допускає, а й вимагає ретельного вивчення й наукової оцінки. Одне з потужних досліджень в такому зв'язку було проведене на замовлення Американської філософської асоціації за підтримки Каліфорнійського університету у Фуллертоні з лютого 1988 по листопад 1989 року. Воно виконувалось за Дельфі-методом із залученням 47 визнаних в полі освіти експертів. Звіт про це дослідження опублікований його науковим керівником Пітером А. Фасіоуном.

Які саме вміння і диспозиції характеризують КМ? У які способи ефективно навчати КМ? Як його можна оцінити у масштабах університетського містечка, округу чи штату? Відповіді на ці основні питання окреслені у консенсусній заяві учасників дослідження.

На нашу думку, критичне мислення має бути цілеспрямованим, здатним до саморегуляції процесом судження, що здійснюється через інтерпретацію, аналіз, оцінку і виведення висновків, а також через усвідомлення фактологічних, концептуальних, методологічних, критеріологічних чи контекстуальних засад, на яких це судження базується. Критичне мислення необхідне як знаряддя дослідницького пошуку (inquiry). Будучи таким, воно є силою вивільнення в освіті й потужним ресурсом особистого та громадянського життя. Не співпадаючи з добрим мисленням (good thinking), KM виявляється усюди проникаючим $і$ здатним до самовиправлення людським феноменом. Ідеальна критично мисляча особа завжди допитлива, добре поінформована, упевнена у розумі, неупереджена, гнучка, справедлива в оцінках, чесна у визнанні своїх прихильностей, зважена у рішеннях, здатна до перегляду власної позиції, ясна у висловлюваннях з обговорюваних питань, впорядковано діюча у складних справах, старанна у пошуку відповідної інформації, розсудлива у доборі критеріїв, зосереджена на пошуку і наполеглива у віднайденні результатів, точних настільки, наскільки дозволяє предмет і обставини дослідження. Тож виховання добре критично мислячих осіб є роботою з досягнення визначеного ідеалу. Воно поєднує розвиток вмінь КМ з плеканням відповідних диспозицій, що в результаті приносить корисні прозріння і становить основу раціонального та демократичного суспільства (Facione, 1990 : p. 2). 
Роз'ясненню і обгрунтуванню цієї короткої заяви та прямо пов'язаних 3 нею питань присвячена решта звіту П. А. Фасіоуна. Але зараз обмежусь лише двома нотатками.

По-перше, не кожен корисний когнітивний процес слід вважати критичним мисленням. Не будь-яке цінне вміння мислити є вмінням КМ. КМ виявляється одним із сімейства щільно пов'язаних форм мислення вищого порядку (higher-order thinking) - урівні, наприклад, з вмінням розв'язувати проблеми, виробляти рішення чи мислити творчо (Facione, 1990 : p. 5).

Наведене зауваження видається сьогодні вкрай актуальним для вітчизняних освітян, оскільки спостерігаються непоодинокі спроби «згорнути усе до однієї купи» 3 брендом «Критичне мислення». Однак такі спроби позбавляють поняття КМ визначеності, вносять плутанину у класифікацію цілей і засобів навчання, вони здатні завдати шкоди навчально-виховному процесові (Тягло, 2017).

Слід зрозуміти, окрім того, що зусилля освітян мусять бути спрямовані на виховання не виключно КМ, а мислення вищого порядку, невід'ємною - але тільки однією - складовою якого є КМ.

По-друге, концептуалізація i, врешті-решт, грунтоване на ній систематичне виховання КМ передбачають пов'язані, однак якісно відмінні виміри: когнітивний та афективний. Перший враховує когнітивні, або пізнавальні, вміння і диспозиції, а другий - афективні диспозиції.

До центральних для КМ когнітивних вмінь експерти фактично одностайно (N > 95\%) віднесли аналіз, оцінку і виведення висновків. Сильна згода ( $>$ > 87\%) виявилась щодо включення до цього осердя КМ інтерпретації, пояснення і саморегуляції, яка включає самоконтроль і самовиправлення (Facione, 1990 : p. 3-4, 6). Без надмірного спрощення можна вважати, що когнітивні вміння в основному грунтуються на природній логіці чи на науці логіки, а також на здатності розуміння чи на герменевтиці: це вміння, що схоплюються у наукових поняттях, піддаються раціональній алгоритмізації та навчанню.

Натомість у описі афективних диспозицій учасники дослідження не уникнули метафор. На їх думку, існує критичний дух (critical spirit), невгамовна допитливість, загостреність думки, ревна відданість правильному мисленню, жага надійної інформації, що властиве добре критично мислячим особам, але відсутне у тих, хто критично мислить слабо. Як вода живить спраглі рослини, так афективні диспозиції створюють підгрунтя для укорінення і розквіту визначених вмінь КМу тих, хто навчається (Facione, 1990 : p. 11).

Афективні диспозиції, як видається, виходять за межі раціонального і навіть свідомого - у підсвідоме, індивідуальне чи соціальне, у природні задатки людини чи у «з молоком матері всмоктані» цінності й звички 
людських спільнот. Тож якщо когнітивним вмінням КМ можна навчати за раціональними алгоритмами, то відповідні афективні диспозиції дитини слід намагатися якомога раніше починати плекати - як висхідні й до певної мірі ще втаємничені підвалини їі мислення, життєдіяльності.

Не входячи зараз у глибини розгляду когнітивного і афективного вимірів людської психіки, можна зрозуміти, що афективні диспозиції становлять підгрунтя дійсності когнітивних диспозицій і вмінь: КМ без них «зависає у повітрі», залишаючись скоріше можливістю мислити критично.

\section{Як виховати критично мислячу особу?}

3 огляду на думку щодо, принаймні почасти, позасвідомої природи афективних диспозицій стає зрозумілішим помітне розходження експертів у ставленні до них. Значна більшість (83\%) погодилась, що добре критично мислячій людині притаманні належні афективні диспозиції, але тільки $61 \%$ учасників дослідження наполягали на посиланні на них у концептуалізації власне КМ (Facione, 1990 : p. 11-14). Так або інакше, але виглядає певнішим не навчати КМ самому по собі, а виховувати критично мислячу особу: тоді розвинуте вміння КМ знаходитиме потрібне підгрунтя здійснення у відповідних когнітивних та афективних диспозиціях. Розпочинати цей процес слід змалку, варіюючи проміжні цілі і форми протягом, щонайменше, дитсадка, шкільної й університетської освіти.

Свідома увага до виховання (fostering) вмінь $і$ диспозицій КМ - мета освіти за усією програмою К-12. Плекання диспозицій КМ, наголос на представленні й оцінці резонів має бути органічною частиною освіти в елементарній школі. Усередній школі відомості щодо різних аспектів і застосувань КМ потрібно інтегрувати до усіх навчальних предметів. А для вступників до коледжів і студентів слід розробити особливі програми вищого рівня та курси з КМ. Хоча в освіті після школи програми з КМ найчастіше асоціюються з кафедрами філософії, ніяк не можна обмежувати в участі у них жоден академічний підрозділ. Адже всеохоплюючі програми з КМ у вишах надаватимуть студентам змогу застосовувати КМ у широкому спектрі тем, обговорюваних питань і проблем (Facione, 1990 : p. 15-16) ${ }^{1}$.

3 наведеного фрагменту зрозуміло, перш за все, що в процесі виховання $K M-з$ огляду як на вміння, так і на диспозиції - виділено низку послідовних стадій. Надалі, вже в обговоренні оцінки КМ, експерти відзначили інтродукційну стадію, стадію практики, стадію інтегрування $i$

${ }^{1}$ Абревіатура К-12 позначає програму дошкільної підготовки (kindergarten) й усіх рівнів повної середньої освіти, загалом зазвичай від чотирьохрічного до сімнадцятирічного віку. 
стадію узагальненого переносу (Facione, 1990 : p. 17). Через співставлення цих двох поділів доходжу висновку, що інтродукційна стадія, в значній мірі спрямована на плекання афективних і когнітивних диспозицій, укорінених, зокрема, у дитячій допитливості, природно відповідає дошкільній підготовці і початковій школі; стадія практики і стадія інтегрування, тобто оволодіння КМ на рівні одиничного та особливого предметного утілення - навчанню у середній школі; стадії узагальненого переносу досягають ті, хто, одержуючи вищу освіту, сходять до сутності KM, осягають його універсальні форми, норми, стандарти ${ }^{1}$.

Визначені північноамериканськими експертами стадії виховання КМ мають загальну природу, їх врахування актуальне і для вітчизняної системи освіти, зокрема у перспективі розбудови «нової української школи». Однак при цьому не припустимо ігнорувати певні особливості, наприклад те, що на першому курсі наших вишів усталеним є курс (загальної) логіки. Це - сприятлива обставина, здатна полегшити і підвищити ефективність навчання КМ.

«Схрещування» звичного для вітчизняних вишів курсу логіки і північноамериканського доробку у сфері КМ несе позитивні наслідки для засвоєння як КМ, так і логіки (Тягло, 2004; 2013).

Навчальний курс логіки з елементами КМ відповідає освітнім потребам студентів-першокурсників. Це має бути не обтяжений формальними численнями курс, структура і зміст якого варіюються залежно від спеціалізації навчання. Його головна мета - забезпечити систематичне усвідомлення і закріплення знань та вмінь не тільки правильного мислення, а й виявлення та (конструктивної) критики типових для повсякденної чи професійної діяльності логічних помилок. Побудований у такий спосіб курс пройшов апробацію у кількох університетах Харкова, він представлений у низці навчальних посібників та підручників (Тягло, 1998; 2001), (Бандурка і Тягло, 2002; 2011).

Курс критичного мислення на основі логіки доцільно адресувати магістрантам. Його особливість полягатиме, перш за все, у постійному зверненні до одержаних раніше знань з логіки, що стосуються загальних законів і форм правильного мислення, їх типових порушень. Це сприятиме переходу від попереднього одиничного чи особливого практикування КМ до осягнення його сутності: тож стадія узагальненого перено-

\footnotetext{
${ }^{1}$ Визначені стадії, як видається, не пов'язані з певним віком жорстко: можна намагатися розвинути вміння КМ і у більш або менш зрілому віці. Однак чи будуть подібні намагання завжди і цілком вдалими, наприклад, коли вже склалися афективні й когнітивні диспозиції, противні тим, що сприяють засвоєнню та практикуванню КМ?! Тож найбільш ефективно усе ж розпочинати процес виховання критично мислячої особи змалку.
} 
су у засвоєнні КМ знайде належне теоретичне підгрунтя у науці логіки. Друга особливість такого курсу - наполеглива додаткова практика у застосуванні КМ, що має сприяти переходу від вмінь до сталих загальних навичок.

Викладання КМ, практиковане мною в університетах Харкова, має ще і третю особливість - доповнення матеріалом щодо творчого мислення та основ композиції наукових праць. Тож пропонований курс не обмежується поданням КМ, почасти орієнтуючись на навчання мисленню вищого порядку. А подання власне КМ передбачає чотири основних блоки: аналіз проблемного повідомлення, його розуміння, оцінку i, у випадку виявлених помилок чи вад, (конструктивну) (само-) критику: тут я, як вже зазначав, загалом спираюсь на підхід Брауна-Кілі (Тягло, 2008).

Описана зв'язка збагаченого елементами КМ курсу логіки і грунтованому на науці логіки курсу КМ, доповненого відомостями щодо творчого мислення і основ композиції, добре відповідає нещодавно уведеним в Україні бакалаврському і магістерському рівням вищої освіти.

Однак досвід свідчить, що сьогодні навчання КМ у вітчизняних вишах досить часто не дає бажаних результатів. Одна з головних причин у тому, що стадії виховання КМ у дитсадках і школах, як правило, губляться. Окрім того, освітня система, що дісталася нам від радянських часів і часто-густо відтворюється дотепер, не спрямована на плекання когнітивних та афективних диспозицій КМ. Аби не бути голослівним, пошлюся на дві авторитетні заяви.

Під час Міжнародної науково-практичної конференції «Демократія і освіта» 2001 року американський фахівець Вільям Глісон, спираючись на дані Всесвітнього Банку, зазначив наступне.

Українці пасуть задніх з огляду на критичне мислення $і$ здатність вирішувати проблеми реального життя, що не мають очевидних і простих рішень... Українська економіка відчуває велику потребу у здатних до новацій і креативних особах, які працювали б за складних та нестандартних умов. Однак освітня система усе ще функціонує по-старому, коли ініціатива та інновації не тільки не заохочувались, але, навпаки, інколи суворо карались (Gleason, 2002 : p. 23).

Минуло півтора десятиліття, і міністр освіти і науки Лілія Гриневич знов визнала: «Освіта залишається чи не єдиною сферою в Україні, що застрягла у радянському минулому з його методами формування особистості, фабричним принципом “всі мають бути однаковими” та знаннєвим підходом - коли на дітей висипають тонну інформації, змушують ї̈ завчити, але не пояснюють, як ицм користуватись та навіщо воно потрібно». I далі вона зауважила, що серед вимог до успішних працівників вже найближ- 
чого майбутнього - вміння вирішувати комплексні завдання, критичне мислення, креативність і т. д. Однак «в Україні дуже мало шкіл, які цьому вчать, і ми мусимо це змінити» (Гриневич, 2017).

Акцентовану чинним міністром увагу до школи як необхідної ланки виховання КМ у складі, фактично, мислення вищого порядку не можна не підтримати. Та слід пам'ятати, по-перше, що відповідні афективні і когнітивні диспозиції дитини потрібно починати плекати ще раніше - принаймні з дитсадка. Тут накопичений досвід, наприклад, програми «Філософія для дітей», яка була розроблена і апробована в університеті Монтклер, а нині поширилась по всьому світові (Адаменко і Кравченко, 2014), (Тищенко, 2016), (Naji and Hashim, 2017). По-друге, реалізація стратегеми Лілії Гриневич вимагає значного часу, і серед перших кроків тут мусить стати рішуче розставання з негативними традиціями «радянського минулого» чи з усюди життєстійким невіглаством, якісна зміна системи підготовки та перепідготовки педагогів. Хотілось би вірити, що на цьому тривалому і непростому шляху освітня система України досягне успіху, хоча швидкоплинна політична кон'юнктура, «залишкове» ставлення до освіти з боку деяких «прагматично налаштованих» можновладців, не усунутий дотепер брак різнопланової мотивації національного педагогічного корпусу в змозі загальмувати просування за вже визначеними світовою науково-педагогічною думкою дороговказами.

\section{Новітні запити на КМ}

Як посилити широку, сталу і дієву підтримку виховання КМ? Не претендуючи на вичерпну відповідь на поставлене запитання, відмічу, що один з найочевидніших способів тут полягає у постійному роз'ясненні усім органічного зв’язку вміння мислити критично з дійсно демократичним суспільним ладом чи відповідною життєдіяльністю окремого громадянина. На це вказували, серед інших, М. Ліпман і його послідовники. Так, М. Грегорі, обговорюючи чесноти демократичного громадянина, зазначив наступне.

Виходитимемо з переконання прагматиків, що пересічні громадяни здатні розвивати майстерні навички пошуку, достатні для вироблення тут-і-зараз доброякісних політичних суджень. Тоді громадянські чесноти - це те, що сприяє участі у даному процесі... Участь у розумному соціальному пошуку також вимагає низки когнітивних і соціальних вмінь. Серед них найбільш значимі вміння критичного і креативного мислення; однак ці вміння необхідно розуміти та практикувати не з огляду на інтуїиї усталених ідеальних соціальних форм, а як вміння, котрі допомагають більш ефективно опрацьовувати (реальні) проблемні ситуації (Gregory, 2004 : p. 165). 
Для України, яка обрала європейський напрям розвитку, КМ виступає імперативом демократизації суспільного життя, чеснотою і засобом виховання свідомого та відповідального громадянина. Поряд з цим «аргументом до демократизації протягом останніх років у нашій країні актуалізувався ще один аргумент на користь виховання КМ: воно є зброєю у інформаційній складовій гібридної війни, котрій не обтяжений належним вишколом здоровий глузд далеко не завжди в змозі протистояти - за виключенням, можливо, явних ексцесів виконання на кшталт подвоєння телеканалом «Россия 24» Зоряна Шкіряка на «представителей украинского истеблишмента Зоряна и Шкиряка».

Звичайно, КМ не є якоюсь «абсолютною зброєю». Але без нього за умов гібридної агресії ззовні і складних внутрішньо-суспільних суперечок ми залишатимемося у значній мірі безпорадними перед витонченою брехнею чи побудованими на «напівправді» технологіями деяких засобів масової інформації, перед впливом недоброякісних соціальних мереж чи пліток, рознесеними «корисними ідіотами» з вулиці, і т. ін.

Зазначене вище виявляє запит на КМ з боку, якщо скористатися термінологією Карла Маркса, надбудови сучасного цивілізованого суспільства. А чи існує подібний запит з боку глибших складових його структури?

3 посиланням на минулорічний Всесвітній економічний форум у Давосі у закордонних і вітчизняних мас-медіа тиражується прогноз, що за умов розгортання Четвертої індустріальної революції у переліку найбільш затребуваних вмінь успішних працівників КМ вже у 2020 році посяде друге місце. Розгляну це твердження уважніше.

Прогностична доповідь «Майбутнє різновидів праці. Професії, вміння і стратегія для робочої сили Четвертої індустріальної революції» була опублікована за два дні до відкриття Давоського форуму - 18 січня 2016 року (The Future..., 2016). А вже 19 січня з'явилася публікація журналістки з британської агенції «Formative Content» Алекс Грей, де з посиланням на цю доповідь були подані списки найбільш затребуваних вмінь успішних працівників у 2015 і у 2020 році, а також короткі коментарі. У переліку 2015 року першими послідовно зазначені вміння розв'язувати складні проблеми, координувати дії з іншими, управляти людьми, критично мислити і вести переговори; у переліку 2020 року - вміння розв'язувати складні проблеми, критично мислити, виявляти креативність, управляти людьми, координувати діï з іншими (Gray, 2016). Приблизно за тиждень схожі матеріали з'явились російською і українською мовами (див., напр. : Четверта промислова..., 2016). Як і Грей, їх автори посилалися на доповідь «Майбутнє різновидів праці...». Проте у ній самій вказаних переліків мені знайти не вдалося, хоча низка міркувань щодо КМ тут справді $є$. 
По-перше, вміння мислити критично розглядається як одне з сукупності 35 вмінь, серцевинних для праці у різних секторах індустрії (core work-related skills) ${ }^{1}$. У такий спосіб КМ виводиться за межі мислення вищого порядку і навіть «чистого мислення» взагалі, принаймні почасти асоціюючись з практичною активністю, з вимогами до успішної праці за часів Четвертої індустріальної революції.

По-друге, визначена сукупність «сериевинних вмінь» не є гомогенною, у ній виділені три особливі категорії - здібності, базові вміння і перехресно-функціональні вміння (abilities, basic skills, cross-functional skills) ${ }^{2}$. Здібності, в свою чергу, поділені на когнітивні (пізнавальна гнучкість, креативність, логічність міркувань та ін.) і фізичні (фізична міцність, вправність і точність рухів); базові вміння - на ті, що стосуються змісту (активне навчання, усне висловлення, розуміння прочитаного, письмове висловлення, інформаційно-комунікаційні технології), і процесуальні (активне слухання, КМ, моніторинг себе й інших); перехресно-функціональні вміння - на соціальні (координація дій з іншими, емоційний інтелект та ін.), системні (судження й вироблення рішень), розв'язання складних проблем, управління ресурсами (управління фінансовими, матеріальними, людськими, а також часовими ресурсами) і технічні (технічне обслуговування і ремонт обладнання, робота на обладнанні і його контроль, програмування та ін.) (The Future..., 2016 : p. 21, 26).

Важливо, що у доповіді «Майбутнє різновидів праці...» (успішній) праці у різних секторах індустрії навіть у першому наближенні співвіднесено не по якомусь одному з 35 «серцевинних вмінь», а у різний спосіб скомбіновані п’ятірки. Вони помітно відрізняються, у тому числі й з огляду на місце КМ, причому не тільки у діахронному, а й у синхронному зрізах. Так, у прогнозі на 2020 рік для сектора «Базова індустрія й інфраструктура» КМ посідає третє місце у п’ятірці, поступаючись когнітивній здібності - чутливості до проблем, а також змістовному вмінню - активно навчатися. У випадку сектора «Фінансові послуги й інвестори» КМ опиняється на четвертому місці, тоді як у випадку сектора «Медіа, розваги й інформування» - на першому (The Future..., 2016 : p. 73, $79,85)$.

\footnotetext{
1 За пропонованим у доповіді роз'ясненням, критичне мислення - це використання логіки і міркування задля ідентифікації сили або слабкості альтернативних рішень, висновків чи підходів до розв'язання проблем (The Future..., 2016 : p. 52).

${ }^{2}$ У загальному випадку, пояснюють укладачі доповіді, у понятті вміння мисляться пов'язані з працею здатності (capabilities) людей виконувати певну роботу успішно. Слід би відрізняти це від поняття здібності, яке схоплює більш фундаментальні й стійкі властивості окремих людей, наприклад когнітивні й фізичні здібності - вони формуються триваліший час, зазвичай починаючи з виховання у ранньому дитинстві (The Future..., $2016:$ p. 54).
} 
3 огляду на сказане намагання а 1а Грей вишикувати в лінійку взяті поодинці «серцевинні вміння», а тим більше усереднено, без врахування поділу індустрії на різні сектори, є подібним до спроби визначити «середню температуру / середній тиск і т. ін. по шпиталю» та ранжувати ці показники як однорідні й значущі самі по собі, незалежно від інших. Звичайно, у такий спосіб якась інформація буде одержана, однак чи становитиме вона надійну підставу правильного діагнозу для конкретного пацієнта, його потреби у належному лікуванні?!

Як «списки Грей», так і грунтований на них висновок щодо переміщення КМ на друге місце серед вмінь успішних працівників 2020 року наразі не виглядають беззаперечними. Найбільш імовірними видаються дві основні версії їх походження: 1) переліки і відповідний висновок містилися в якихось додаткових до доповіді «Майбутнє різновидів праці...» роз’ясненнях, поданих учасникам форуму у Давосі й акредитованим там журналістам, але ширшій аудиторії не пред’явлених; 2) вони є артефактом особистої - оперативної, але досить поверхневої - реакції Алекс Грей та деяких іiі послідовників на немалу за обсягом і зовсім непросту за змістом доповідь ${ }^{1}$. Так чи інакше, усе це вимагає додаткового вивчення й оцінки, наразі зберігаючи значний потенціал переконання хіба що для тих політиків, чиновників та «акул пера», котрі за браком часу чи наснаги не прагнуть вникати у питання глибоко.

Та навіть без урахування «списків Грей» $з$ доповіді Давоського форуму випливає низка важливих для КМ висновків. Перш за все, як вже було відмічено, вміння мислити критично пов'язується не тільки з мисленням - навіть вищого порядку, а і з працею, з вимогами до якісної сьогодні й у прогнозованому майбутньому робочої сили. Тож воно асоціюється з продуктивними силами суспільства і з властивим йому способом виробництва, що, коли знову згадати Маркса, обумовлює соціальний, політичний і духовний процеси життя загалом, є рушійною силою суспільного поступу (Маркс, 1959 : с. 6-7). Таким чином, запит на КМ виявляється як з боку надбудови, так і продуктивних підвалин конкурентноздатного у XXI столітті суспільства!²

Окрім того, критика надто спрощеного лінійного ранжування окремих вмінь успішних працівників і беззастережного приписування у прогнозі на 2020 рік вмінню КМ саме другого місця у загальному переліку

\footnotetext{
${ }^{1}$ Хоча повідомлення Грей розміщене на сайті Давоського форуму, але одразу після нього додане застереження: висловлені у цьому повідомленні погляди належать самій авториі, а не Світовому економічному форуму.

${ }^{2}$ Можна по-різному ставитися до марксизму і його висновків. Проте щонайменше зі сказаного випливає наявність у сучасному суспільстві кількох важливих джерел запитів на вміння КМ.
} 
зовсім не виключає того, що воно дійсно знаходитиметься серед найбільш затребуваних. Справді, за прогнозом доповіді «Майбутнє різновидів праці...» воно присутнє у перших п’ятірках у семи з дев’яти розглянутих секторів індустрії, в тому числі в одному секторі - на першому місці, у трьох - на другому, у двох - на третьому, в одному - на четвертому. Для порівняння зауважу, що вміння розв’язувати складні проблеми у перших п’ятірках найбільш значущих вмінь даних секторів індустрії згадується лише шість разів, хоча у п'яти з них - на першому місці, у одній - на третьому; креативність згадується у складі трьох п’ятірок, по одному разу на першому, четвертому і п’ятому місцях. Таким чином, виховання КМ у складі «серцевинних вмінь» успішних працівників дійсно відповідає викликам XXI століття, а його підтримка мусить бути справою не тільки передових педагогів, демократично налаштованих політиків чи відповідальних громадян сучасних цивілізованих країн, а й далекоглядних можновладців різних рівнів.

\section{Основні висновки}

КМ сьогодні потрібно вивчати і осмислювати як один з суттєвих елементів складніших утворень - мислення вищого порядку, сукупності серцевинних для (успішної) праці вмінь тощо. Тож виглядає проявом нерозуміння чи недолугої кон'юнктури згортання різних складових елементів, наприклад, мислення вищого порядку «до однієї купи» під брендом «Критичне мислення», що спостерігається в публікаціях окремих представників вітчизняної педагогіки. Висновок стосовно зростання вже у перспективі 2020 року запиту на КМ сам по собі є досить показовим, але його обгрунтування а lа Грей надто спрощує розуміння сукупності серцевинних для праці вмінь і тому вразливе для критики.

Вміння КМ потрібно вивчати і осмислювати, зрештою - розвивати у зв’язку з відповідними когнітивними і афективними диспозиціями. Без випереджувального плекання цих диспозицій навчання КМ навряд чи даватиме бажані результати, оскільки залишатиметься скоріше можливістю мислити критично, здійснення якої суттєво залежатиме від випадкового збігу обставин.

Правильнішим є не обмежуватися навчанням КМ, а виховувати критично мислячу особу, в якої вміння КМ спиратиметься на підвалини відповідних афективних і когнітивних диспозицій. Процес виховання критично мислячої особи, а вірніше - особи, котра матиме КМ, наприклад, у складі сукупності серцевинних для ii праці вмінь, бажано починати 3 дитсадка, він має тривати щонайменше протягом дошкільної, шкільної й університетської освіти. Цей процес передбачає низку послідовних 
стадій, кожній з них відповідають свої цілі й критерії успішності. Коли якась 3 цих стадій губиться, ефективність навчання і, зрештою, практикування КМ може бути зведена нанівець.

За умов вітчизняної вищої школи в процесі розвитку КМ доцільно використовувати зв’язку курсу логіки з елементами критичного мислення - у межах бакалаврату - і курсу критичного мислення на основі логіки - у межах магістратури. Однак було б помилкою обмежуватись тільки цими курсами: виховання КМ можна і потрібно уводити у викладання будь-якої академічної дисципліни, тим самим підвищуючи ефективність засвоєння не тільки КМ, а й відповідної дисципліни, осучаснюючи освітній процес загалом.

У XXI столітті запити на вміння КМ визначаються потребами як надбудови цивілізованого суспільства («аргумент до демократії», «аргумент до демократизації», «аргумент зброї у інформаційній війні» тощо), так і його продуктивних сил. КМ є і у передбачуваному майбутньому залишатиметься одним з «сериевинних вмінь» успішного працівника часів Четвертої індустріальної революції - у доцільній комбінації, звичайно, з вмінням розв'язувати складні проблеми, креативністю і т. ін. Успішне суспільство не відбудеться без ясного усвідомлення цієї обставини й відповідної активності педагогів, політиків та можновладців, найширших верств відповідальних громадян.

Література / References:

1. Адаменко Н., Кравченко Ю. (2014) Історія знайомства української педагогічної аудиторії з методикою «Філософія для дітей» / Філософія освіти. Philosophy of Education, 2(15), 188-194. URL: www.philosopheducation.com

Adamenko, Nadiya and Kravchenko, Yuliya (2014) The History of Ukrainian Pedagogues' Knowledge of the Methodology "Philosophy for Children" / Філософія освіти. Philosophy of Education, 2(15), 188-194 (in Ukrainian). URL: www. philosopheducation.com

2. Бандурка О. М., Тягло О. В. (2002) Курс логіки. Підручник. Київ : Літера ЛТД. Bandurka, Oleksandr and Tiaglo, Oleksandr (2002) Course of Logic. A Textbook. Kyiv: Litera Ltd. (in Ukrainian).

3. Бандурка О. М., Тягло О. В. (2011) Юридична логіка : підручник для студентів вищ. навч. закладів. Харків : Золота миля.

Bandurka, Oleksandr and Tiaglo, Oleksandr (2011) Juridical Logic: A Textbook for the Higher-school Students. Kharkiv : Golden Mile (in Ukrainian).

4. Вайнстейн М. (2005) Каркас для критического мышления / Постметодика, 2(60), 42-45.

Weinstein, Mark (2005) A Framework for Critical Thinking / Postmethodika, 2(60), 42-45 (in Russian).

5. Гайденко В. (2006) Філософія освіти в Бразилії : критична педагогіка Пауло Фрейре // Філософія освіти. Philosophy of Education, 2(4), 91-99. URL: www.philosopheducation.com 
Haydenko, Viktoria (2006) Philosophy of Education in Brazil: Paulo Freire's Critical Pedagogy / Філософія освіти. Philosophy of Education, 2(4), 91-99 (in Ukrainian).

URL: www.philosopheducation.com

6. Грегорі М. (2006) Про філософію, дітей та «заборонені теми» / Виховна робота в школі, 6(19), 12-13.

Gregory, Maughn (2006) On Philosophy, Children and Taboo Topics / Educational Work in School, 6(19), 12-13 (in Ukrainian).

7. Гриневич Л. (2017) Надто важливий. Чому потрібно прийняти новий закон про освіту? / Українська правда. Життя. URL: https://life.pravda.com.ua/ columns/2017/06/19/224784/

Grinevich, Liliya (2017) Too Important. Why to Adopt a New Law on Education? / Ukrainian Truth. Life. URL: http://life.pravda.com.ua/columns/2017/06/19/224784/ (in Ukrainian).

8. Ліпман М. (2005) Критичне мислення: чим воно може бути? / Постметодика, 2(60), 33-41.

Lipman, Mathew (2005) Critical Thinking: What Can It Be? / Postmethodika, 2(60), 33-41 (in Ukrainian).

9. Макларен П. (2010) Революційна критична педагогіка у XXI ст. Відповіді на запитання Ірини Предборської / Філософія освіти. Philosophy of Education, 1-2 (9), 57-66.

URL: www.philosopheducation.com

McLaren, Peter (2010) Revolutionary Critical Pedagogy of 21th Century (Interview with Iryna Predborska) / Філософія освіти. Philosophy of Education, 1-2(9), 57-66 (in Ukrainian).

URL: www.philosopheducation.com

10. Маркс К. (1959) К критике политической экономии / Маркс К., Энгельс Ф. Сочинения. 2-е изд. Т. 19. Москва: Госполитиздат.

Marx, Karl (1959) A Contribution to the Critique of Political Economy / Marx, Karl and Engels, Frederic. $2^{\text {nd }}$ ed. Collected Works, vol. 19. Moscow : State Publishing House of Political Literature (in Russian).

11. Терно С. (2012) Світ критичного мислення: образ та мімікрія / Історія в сучасній школі, 7-8, 27-38.

Terno, Sergiy (2012) World of Critical Thinking: Real Form and Mimicry / History in Today School, 7-8, 27-38 (in Ukrainian).

12. Тищенко К. (2016) Зубрити - не вихід. Як у школах вчитимуть критичному і креативному мисленню / Українська правда. Життя.

URL: https://life.pravda.com.ua/society/2016/07/5/214729/

Tyshchenko, Katerina (2016) To bite is not a way out. How in schools will learn critical and creative thinking / Ukrainian Truth. Life.

URL:https://life.pravda.com.ua/society/2016/07/5/214729/ (in Ukrainian).

13. Тягло А. В. (1996) Логика критического мышления (в конспективном изложении). Харьков : Харьковский институт управления.

Tiaglo, Alexander V. (1996) Logic of Critical Thinking (In a Concise). Kharkov : Kharkov Institute of Management (in Russian).

14. Тягло А. В. (2001) Критическое мышление на основе элементарной логики. Учебное пособие. Харьков : ХНУ им. В. Н. Каразина. 
Tiaglo, Alexander V. (2001) Critical Thinking on Base of Elementary Logic. Kharkov, Vasili Karazin Kharkov National University (in Russian).

15. Тягло А. В. (2004) Современная «наука рассуждать» / Постметодика, 2-3(54-55), 2-10.

Tiaglo, Alexander V. (2004) Today "Science of Reasoning" / Postmethodika, 2-3(5455), 2-10 (in Russian).

16. Тягло А. В. (2013) «Наука рассуждать» в «быстром мире» / Философские науки, 3, 129-136.

Tiaglo, Alexander V. (2013) The "Science of Reasoning" in the "Fast World" / Philosophical Sciences, 3, 129-136 (in Russian).

17. Тягло А. В., Воропай Т. С. (1999) Критическое мышление: Проблема мирового образования XXI века. Харьков : Университет внутренних дел.

Tiaglo, Alexander V. and Voropai, Tatiana S. (1999) Critical Thinking: A Challenge to the XXI-st Century Education. Kharkov : University of Internal Affairs (in Russian).

18. Тягло О. В. (1998) Логіка з елементами курсу критичного мислення. Харків : Видавництво Університету внутрішніх справ, «Основа».

Tiaglo, Oleksandr V. (1998) Logic with Elements of Critical Thinking. Kharkiv : University of Internal Affairs Publishing House, "Osnova" (in Ukrainian).

19. Тягло О. В. (2005) Післямова до статей Метью Ліпмана і Марка Вайнстейна / Постметодика, 2(60), 46-47.

Tiaglo, Oleksandr V. (2005) Afterword to the Papers of Mathew Lipman and Mark Weinstein / Postmethodika, 2(60), 46-47 (in Ukrainian).

20. Тягло О. В. (2008) Критичне мислення : навчальний посібник. Харків : Видавництво «Основа».

Tiaglo, Oleksandr V. (2008) Critical Thinking : A Manual. Kharkiv : "Osnova” Publishing House (in Ukrainian).

21. Тягло О. (2017) Чи буде культура критичного мислення в новій українській школі? / Українська правда. Життя. URL: http://www.life.pravda.com.ua/ columns/2017/02/9/222533/

Tiaglo, Oleksandr. Will the culture of critical thinking in the new Ukrainian school? / Ukrainian Truth. Life. URL: http://www.life.pravda.com.ua/columns/2017/02/9/222533/ (in Ukrainian).

22. Четверта промислова революція (2016) / Tech Today. URL:https://techtoday.in.ua/ news/chetverta-promislova-revolyuciya-56779.html

The Fourth Industrial Revolution (2016) / Tech Today. URL:https://techtoday.in.ua/ news/chetverta-promislova-revolyuciya-56779.html (in Ukrainian).

23. Brown, M. Neil and Keeley, Stuart M. (1998) Asking the Right Questions. A Guide to Critical Thinking. $5^{\text {th }}$ ed. Upper Saddle River (NJ): Prentice Hall.

24. Burbules, N. and Berk, R. (1999) Critical Thinking and Critical Pedagogy / T. S. Popewitz \& L. Fender (eds). Critical Theories in Education. New York: Routledge.

25. Facione, Peter A. (1990) Critical Thinking: A Statement of Expert Consensus for Purposes of Educational Assessment and Instruction. Executive Summary. "The Delfi Report". Millbrae, CA : The California Academic Press.

26. Gleason, William (2002) Ukrainian Higher Education in Transition: Perspectives and Policy Implications / Conference Proceedings "Democracy and Education”, June 1-2, 
2001, Kyiv, Ukraine. Washington, D. C. : Montclair State University Global Education Center, Literal Books.

27. Gray, Alex (2016) The 10 Skills You Need to Thrive in the Fourth Industrial Revolution. URL:https://www.weforum.org/agenda/2016/01/the-10-skills-you-need-to-thrive-inthe-fourth-industrial-revolution/

28. Gregory, Maughn (2004) Practicing Democracy: Social Intelligence and Philosophical Practice / International Journal of Applied Philosophy, 18(2), 161-174.

29. Naji, Saeed and Hashim, Rosnani (eds.) (2017) History, Theory and Practice of Philosophy for Children. NY : Routledge.

30. The Future of Jobs. Employment, Skills and Workforce Strategy for the Fourth Industrial Revolution (2016). URL: http://www3.weforum.org/docs/WEF_Future_of_Jobs.pdf

\section{Александр Тягло. Опыт усвоения критического мышления в украинской высшей школе}

В статье аргументировано, что в XXI столетии запросы на критическое мышление (KM) будут определяться потребностями как политической надстройки, так и производительных сил конкурентоспособного общества. Феномен КМ нужно изучать и осмысливать как один из существенных элементов более сложных образований - мышления высшего порядка, совокупности сердцевинных для труда умений и др. Умение КМ следует развивать в связи с соответствующими когнитивными и аффективными диспозициями. Поэтому подчеркнуто, что более правильно не ограничиваться обучением КМ, а воспитывать критически мыслящую личность, у которой умение КМ будет опираться на основания соответствующих диспозиций. Процесс воспитания критически мыслящей личности, а вернее - личности, которая будет иметь КМ, например, в составе совокупности сердцевинных для ее труда умений, должен охватывать, как минимум, дошкольное, школьное и университетское образование. Обосновано, что в условиях украинской высшей школы в процессе воспитания КМ целесообразно использовать связку двух курсов: логики с элементами критического мышления - в рамках бакалаврата - и критического мышления на основе логики - в рамках магистратуры.

Ключевые слова: критическое мышление, критически мыслящая личность, мышление высшего порядка, сердцевинные для труда умения, высшая школа Украины.

Oleksandr Tiaglo. Experience of Mastering of Critical Thinking in the Ukrainian Higher Education

It is argued in this paper that demands for critical thinking (CT) will be determined by needs both of political superstructure and productive forces of a competitive society in the 21 st century. Phenomenon of CT has to be studied and understood as one of the essential elements of some more complex entities higher-order thinking, core of work-related skills, etc. CT skill need to be developed in connection with relevant cognitive and affective dispositions. It is pointed out, 
therefore, that it is more correct not to be limited by teaching CT but to educate a critical thinker, whose CT skill is relied on base of relevant dispositions. The process of educating a critical thinker, or rather - a person who will have CT, for instance, as element of a set of the core work-related skills, should continue during the kindergarten, school and university education at least. It is substantiated that under conditions of Ukrainian higher education it is expediently to use two interconnected courses in the process of CT education: logic with elements of critical thinking - in frame of the bachelor's degree studies - and critical thinking on base of logic - in frame of the master's degree studies.

Key words: critical thinking, critical thinker, high-order thinking, core workrelated skill, Ukrainian higher education.

Тягло Александр - доктор философских наук, профессор, профессор кафедры социально-гуманитарных дисциплин Харьковского национального университета внутренних дел.

E-mail: olexti@gmail.com

Tiaglo, Oleksandr - Doctor of Philosophy, Professor, Professor of the Department of Social and Human Disciplines at the Kharkiv National University of Internal Affairs (Ukraine).

E-mail: olexti@gmail.com 